\title{
Factors Affecting the Incidence of Group A $\beta$-Hemolytic Streptococci Isolated from Throat Culture
}

\section{Boğaz Kültüründen İzole Edilen A Grubu $\beta$-Hemolitik Streptokokların Görülme Sıklığını Etkileyen Faktörlerin Araştırılması}

\author{
Esra Deniz Candan ${ }^{1 *}$, Neslihan İdil ${ }^{\circledR}$ and Abbas Yousefi Rad ${ }^{3}$ \\ ${ }^{1}$ Department of Medical Services and Techniques, Health Services Vocational School, Giresun University, Giresun, Turkey. \\ ${ }^{2}$ Department of Biology, Faculty of Sciences, Hacettepe University, Ankara, Turkey. \\ ${ }^{3} \mathrm{Clinical}$ Microbiology, Koru Hospitals, Yüksek Ihtisas University, Ankara, Turkey.
}

\section{ABSTRACT}

roup A beta-hemolytic streptococci (GABHS) rank first among bacterial factors causing tonsillopharyngitis. These bac $\exists$ teria are especially common in school-age groups. The incidence increases in winter and seasonal transitions. In this study, we aim to examine the presence of GABHS in throat swab samples of people from different age groups. Therefore, we identified the reproductive frequency of GABHS in the throat culture of patients admitted with tonsillopharyngitis from 2017 to 2019 and then detected differences in the infection across age groups, months, and seasons. It was found that $8.1 \%$, $52.4 \%, 21.5 \%$, and $11.0 \%$ of isolated factors were in the age groups of $0-2,3-6,7-9$, and $10-14$, respectively. Particularly, in the 3-14 age group, the number of cases accounts for $84.9 \%$ of the total number of cases. The highest rate of infection was observed in children aged 3-6 years, and the infection was quite high in the spring (34.5\%) and winter (29\%). Regarding the distribution of the factor across clinics, the Department of Pediatrics was the first, and the Department of Pediatric Nephrology and Rheumatology was the second. In conclusion, controlling the spread of infections at school age is of great importance as GABHS has increased over the years.

\section{Key Words}

Group A beta-hemolytic streptococci, incidence, school children, tonsillopharyngitis.

\section{öz}

Grubu Beta Hemolitik Streptokoklar, tonsillofarenjite neden olan bakteriyel etkenler arasında ilk sırada yer almaktadır.

Söz konusu bakteriler özellikle okul çağı yaş gruplarında sıklıkla görülmektedirler. Kış ayları ve mevsim geçişlerinde görülme sıklığında artış meydana gelmektedir. Çalışma kapsamında farklı yaş gruplarına ait kişilerin boğaz sürüntü örneklerinde $A$ Grubu Beta Hemolitik Streptokok varlığının araştırılması amaçlanmıştır. Bu amaçla, 2017-2019 yılları arasında tonsillofarenjit belirtisi ile başvuran hastaların boğaz kültüründe A Grubu Beta Hemolitik Streptokok üreme sıklığı belirlenerek, aynı zamanda enfeksiyonunun yaş grupları, aylar ve mevsimler arası farklılıkları saptanmıştır. Çalışmamızda izole edilen etkenlerin \%8.1'i, 0-2, \%52.4'ü, \%21.5'i 7-9, \%11.0'i 10-14 yaş aralığında olduğu tespit edilmiştir. Hastalar yaş gruplarına göre değerlendirildiğinde; özellikle 3-14 yaş aralığındaki toplam vaka sayısı toplam vaka sayısının \%84,9'ini oluşturmaktadır. Enfeksiyon oranının en yüksek 3-6 yaş arası çocuklarda görüldüğü ve ilkbahar (\%34.5) ve kış (\%29) aylarında oldukça yüksek oranda görüldüğü saptanmıştır. Çalışmamızda etkenin poliklinikler arasındaki dağılımda; Pediatri Bölümü ilk, Çocuk Nefrolojisi ve Romatoloji Bölümü ise ikinci sırada yer almaktadır. Sonuç olarak, A Grubu Beta Hemolitik Streptokokların yıllar içerisinde artış göstermesi nedeniyle, özellikle okul çağında görülen enfeksiyonların yayılımının kontrol altına alınmasının büyük önem taşıdığı açıkça görülmektedir.

\section{Anahtar Kelimeler}

A Grubu beta hemolitik streptokoklar, görülme sıklığı, okul çağı; tonsillofarenjit. 


\section{INTRODUCTION}

treptococcus pyogenes is defined as Group A Beta-He$\int$ molytic Streptococci (GABHS) according to its antigenic properties in the polysaccharide structure located in the cell wall. S. pyogenes causes suppurative infections in humans including pharyngitis, scarlet fever, erysipelas, and pyoderma. Moreover, it is also a factor in important nonsuppurative infections that occur as acute rheumatic fever and acute glomerulonephritis [1]. GABHS are the microorganisms that rank first among bacterial factors in $20-40 \%$ of pharyngitis in children between the ages of $5-15$ and in 5-10\% of adults [2]. The increasing incidence of this infection over the years and the high morbidity and mortality in post-streptococcal complications that develop due to the infection demonstrate that GABHS cases are currently very important [3]. Therefore, it is necessary to determine effective treatment methods with fast and accurate identification of the causative microorganism to avoid complications such as acute rheumatic fever and acute glomerulonephritis.

The incidence of GABHS varies depending on several factors including age, gender, geographical region, socioeconomic level, climate, and season [4-5]. Moreover, the type of population at risk for infection is also an important factor. Acute tonsillopharyngitis caused by GABHS can be in all age groups regardless of gender. Although it is quite rare in children under the age of 3 , it is more common in early school age groups. It begins to decrease in adolescence and adult age groups [6]. Especially in school children between the ages of 5-15, it occurs at the end of the winter and the beginning of the spring [6]. Also, it is among the reasons for frequent referrals to physicians and one of the most common reasons for antibiotic use.

Upper respiratory tract infections are one of the most common infections in childhood. Tonsillopharyngitis caused by GABHS maintains its importance as an endemic disease in developing countries. Streptococcal pharyngitis is quite common in children in daycare centers. Its transmission occurs by the inhalation of microorganisms in large droplets or direct contact with respiratory secretions [7]. The annual incidence ranges from 100 to 200 in 10,000 school-age children. If infected children are not effectively treated, its transmission occurs approximately with a rate of $35 \%$. Rheumatic fever has been reported in 1-3\% of streptococcal throat infections, especially in children in a low socioeconomic status [8].
In clinical practice, taking a throat culture from people with tonsillopharyngitis is a common practice for all age groups. In our study, we examined the presence of GABHS in throat swab samples of people belonging to different age groups. Within the scope of the study, the frequency of reproduction of GABHS in the throat culture of patients admitted with tonsillopharyngitis symptoms between 2017 and 2019 was determined, as well as differences in infection between age groups, months, and seasons were detected.

\section{MATERIALS and METHODS}

Streptococcal strains and patient characteristics were retrospectively analyzed in throat swab samples from patients who were hospitalized or applied to the outpatient clinic between January 2017 and December 2019 in a private research hospital in Ankara, Turkey. Throat swab samples were received from a total of 14,371 patients who were admitted with tonsillopharyngitis symptoms.

This study included 1775 patients with the reproduction of Streptococcus spp. isolated specimens were classified as age, gender, and Streptococcus group, as well as the distribution of these specimens across years, seasons, and months. Patients were aged 0-2 years (144 patients), 3-6 years (927 patients), 7-9 years (381 patients), 10-14 years (194 patients), 15-19 years (14 patients), 20-29 (15 patients), 30-39 years old (68 patients) and over 40 years old (27 patients)

Isolated strains were identified using an automated identification system (BD PhoenixTM, BD Diagnostic Systems Sparks, MD, USA). Test microorganisms were inoculated onto Blood agar plates for monitoring the beta-hemolytic colonies directing the identification towards S. pyogenes strains. After 24 hours cultivation at $35-37^{\circ} \mathrm{C}$, colonies surrounded by a zone of beta-hemolysis are observed as white-grayish dome-shaped colonial morphology of a smooth or moist surface and clear margins. The microscopic morphology of $S$. pyogenes is spherical arranging in chains or pairs. Bacitracin sensitivity test were applied for differentiating. S. pyogenes from other non-Group A beta-hemolytic streptococcal strains. Besides, Lancefield Antigen A test was applied for strong specificity make accurate identification for $S$. pyogenes $[9,10]$. 


\section{RESULTS and DISCUSSION}

This study determined the reproductive frequency of GABHS in the throat culture of people who were admitted with signs of fever or upper respiratory tract infection. Moreover, differences between certain age groups and years of this infection were detected. Our study included a total of 14,371 throat swab samples of which GABHS were present in 1,770 (12.3\%) patients and Group $G$ in three patients. Two patients included non-Group A beta-hemolytic streptococcus.
The distribution of factors reproducing in throat cultures across months is presented in Figure 1 . The monthly number of patients was calculated by taking the monthly mean of the cases between 2017 and 2019. While the least number of cases were detected in August (16 cases) and July (18 cases), the highest cases were in May (71 cases) and November (72 cases) (Fig.1.).

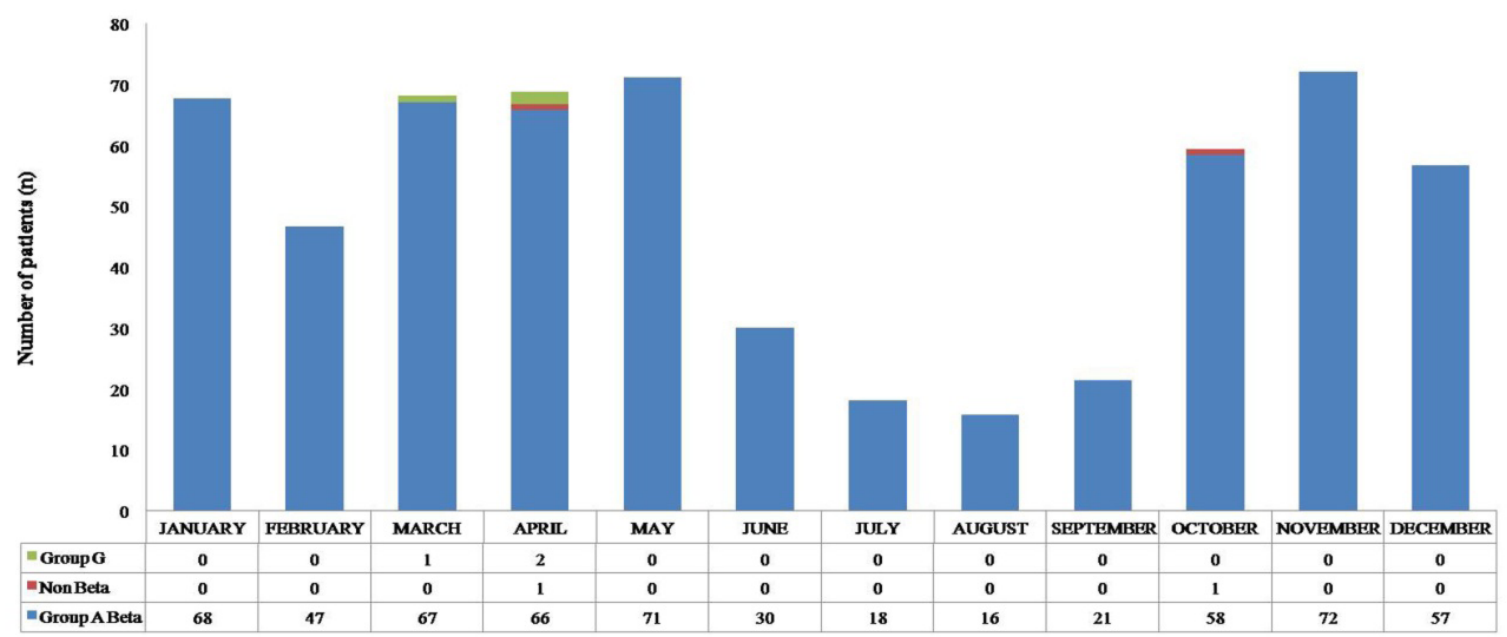

Figure 1. The distribution of isolated Streptococci ( $N=1775)$ across months between 2017 and 2019. Numerical values indicate the mean number of cases each month.

Table 1. Demographic characteristics of GABHS isolated between 2017 and 2019.

\begin{tabular}{cc}
\hline Demographic factors & $N=1,770$ \\
\hline Gender & $907(\% 51.2)$ \\
\hline Male & $863(\% 48.8)$ \\
\hline Female & \\
\hline Age group & $144(\% 8.1)$ \\
\hline $0-2$ & $927(\% 52.4)$ \\
\hline $3-6$ & $381(\% 21.5)$ \\
\hline $7-9$ & $194(\% 11.0)$ \\
\hline $10-14$ & $14(\% 0.8)$ \\
\hline $15-19$ & $15(\% 0.8)$ \\
\hline $20-29$ & $68(\% 3.8)$ \\
\hline $30-39$ & $27(\% 1.5)$ \\
\hline $40+$ & $1,768(\% 99.9)$ \\
\hline Treatment type & $2(\% 0.1)$ \\
\hline Outpatient & \\
\hline Inpatient &
\end{tabular}


The distribution of the most isolated GABHS infection factors across gender, age groups, and treatment type are provided in Table 1 . We found that $51.2 \%$ of patients with GABHS were male and $48.8 \%$ were female. Moreover, $99.9 \%$ of patients received outpatient treatment. Positive results were found in only two inpatients.

A significant similarity between GABHS strains that cause pharyngitis in school-age children and isolates from cases of the invasive disease in the community suggests that this age group serves as a reservoir of the infection [11-12]. Regarding the distribution of GABHS across clinics, in our study, $75.6 \%(1,339$ of 1,770$)$ of the cases were in the pediatrics department including the age ranges of 3-6, 7-9, and 10-14 (Table 2).

Post-streptococcal glomerulonephritis is described as the most common form of post-infectious glomerular damage. The disease occurs in 5\% of those infected with streptococcal sore throat and can occur in $25 \%$ of infections with nephritogenic strains of beta-hemolytic streptococci. It is estimated that more than 470,000 cases of acute post-streptococcal glomerulonephritis occur annually. Especially in underdeveloped countries, the incidence in children was 24.3 cases per 100,000 people annually [13]. In our study, the distribution of the same factor across clinics ranks second with 180 cases in the Department of Pediatric Nephrology and Rheumatology.
The distribution of GABHS across gender and age ranges is presented in Fig.2. No significant difference was observed when patients are evaluated according to their gender (Fig. 2.). Similarly, no significant gender difference was detected in a study with 487 children [14].

Regarding the age groups, the 3-14 age group accounted for $84.9 \%$ (1502) of the total number of cases. Among these cases, the number of cases is quite remarkable in the age group of 3-6. The number of cases in the age of 15 and over significantly decreased. Besides, an increase in cases was detected in the age group of 30-39. Of isolated factors, $8.1 \%(144 / 1770)$ was in the age group of $0-2,52.4 \%(927 / 1770)$ in $3-6,21.5 \%$ (382/1770) in $7-9$, and $11.0 \%(194 / 1770)$ was in the age group of $10-14$. In another study, 125 of 369 patients were in the 1-5 age group and it was the age group with the highest cases [15].

Of 1,770 GABHS isolated between 2017 and 2019 in our study, $34.5 \%$ were isolated in spring, $29 \%$ in winter, $25.7 \%$ in autumn, and $10.8 \%$ in summer (Fig. 3.). In another study, these values were 5.42\% (51/941) in spring, $3.88 \%(23 / 592)$ in summer, $7.13 \%(69 / 968)$ in autumn, and $7.76 \%$ (125/1611) in winter [16]. Moreover, ÖzkayaParlakay et al. (2012) found that April and October were the least common months of infection, whereas, in our study, the cases were very low between June and September [17].

Table 2. Distribution of GABHS across clinics.

\begin{tabular}{cccccc}
\hline Clinics & 2017 & 2018 & 2019 & Mean & Total \\
\hline Pediatrics & 362 & 467 & 510 & 446 & 1,339 \\
\hline Pediatric Nephrology and Rheumatology & 55 & 54 & 71 & 60 & 180 \\
\hline Otorhinolaryngology & 27 & 23 & 67 & 39 & 117 \\
\hline Pediatric Endocrine & 22 & 15 & 15 & 17 & 52 \\
\hline dermatology & 19 & 8 & 8 & 12 & 35 \\
\hline Internal Medicine & 2 & 10 & 10 & 7 & 22 \\
\hline Pediatric Neurology & 9 & 1 & 0 & 3 & 10 \\
\hline Laboratory & 2 & 2 & 1 & 2 & 5 \\
\hline Pediatric Cardiology & 1 & 1 & 2 & 1 & 4 \\
\hline Emergency & 0 & 1 & 2 & 1 & 3 \\
\hline Pulmonology & 1 & 0 & 0 & 0 & 1 \\
\hline Rheumatology & 1 & 0 & 0 & 0 & 1 \\
\hline Urology & 1 & 0 & 0 & 0 & 1 \\
\hline
\end{tabular}


We found significant differences across populations regarding the transmission rate of GABHS. These differences may depend mainly on many other factors including socioeconomic conditions, seasons, and age [16, 18-19]. In conclusion, our study determined that GABHS infection tends to increase over time, and the highest infec- tion rate was detected in children aged 3-6 years. We also found that the infection was quite high in spring and winter.

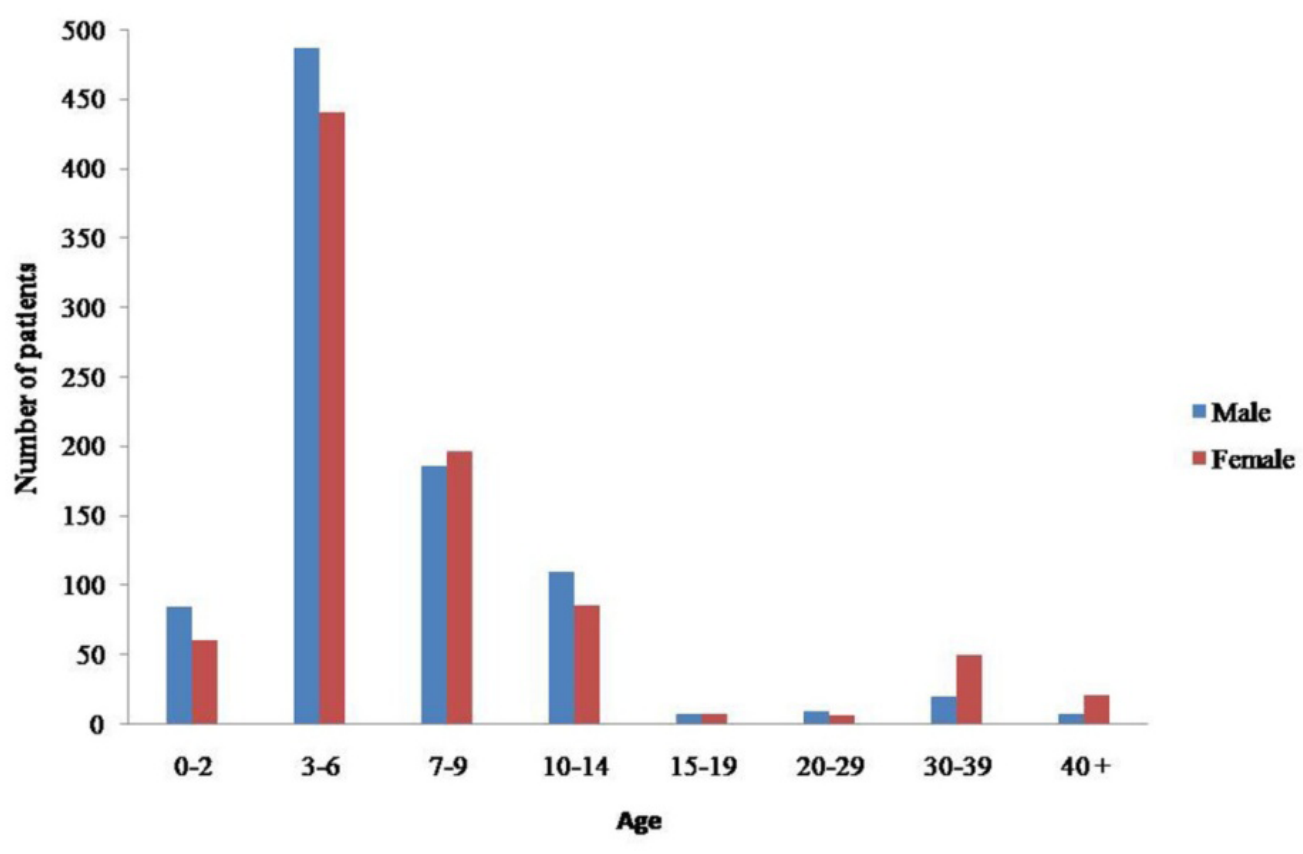

Figure 2. The distribution of GABHS across gender and age groups.

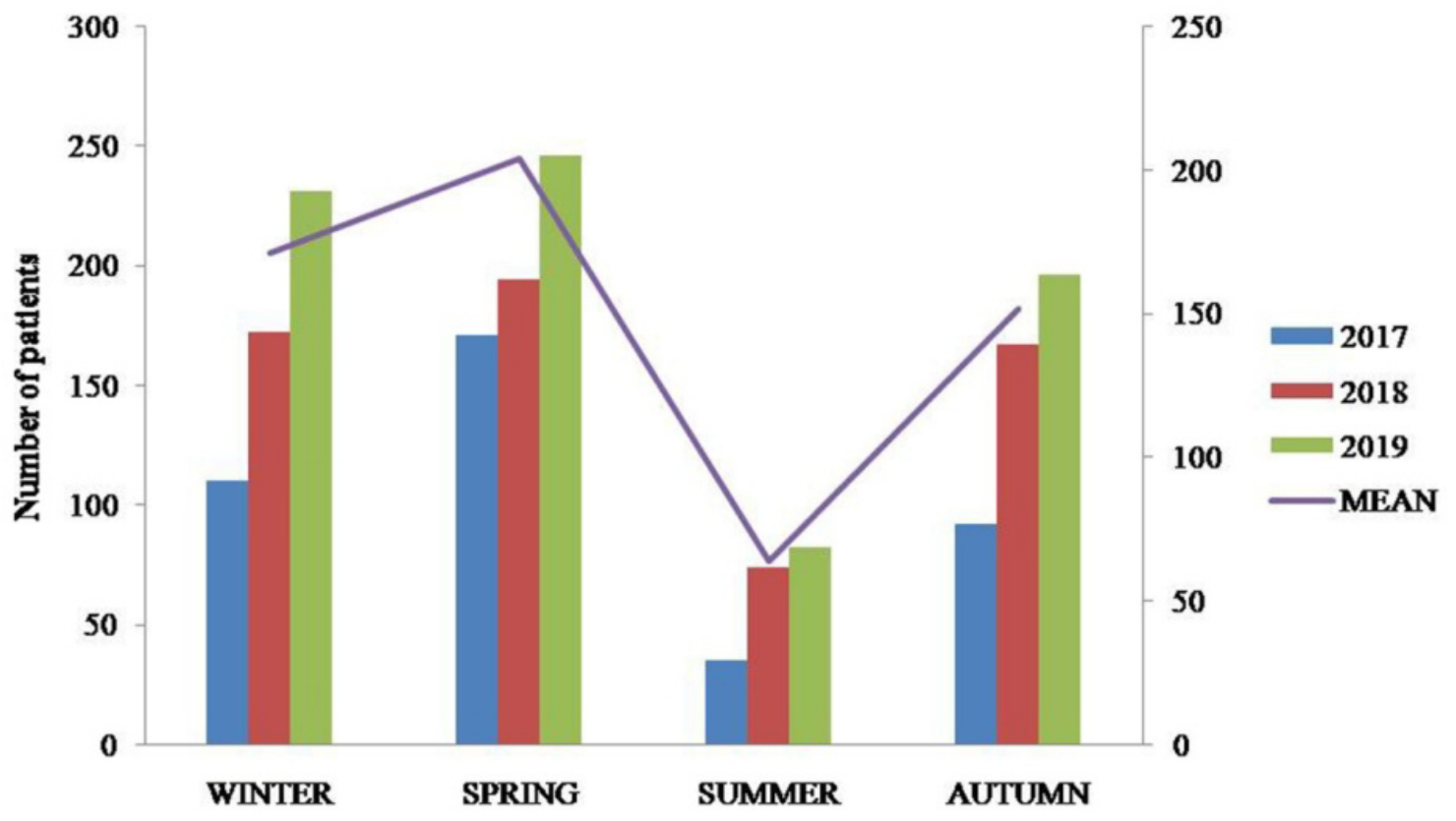

Figure 3. The distribution of GABHS across seasons and years. 


\section{Acknowledgments}

We thank Fatih Fazlıoğlu, PhD., for linguistic advice and criticism.

\section{References}

1. W.L. Lean, S. Arnup, M. Danchin, A.C. Steer, Rapid diagnostic tests for group A streptococcal pharyngitis: A meta-analysis, Pediatrics, 134 (2014) 771-781.

2. J.F. Cohen, M. Chalumeau, C. Levy, P. Bidet, F. Thollot, A. Wollner, E. Bingeni, R. Cohen, Spectrum and inoculum size effect of a rapid antigen detection test for group A streptococcus in children with pharyngitis, PLoS One, 7:e39085 (2012).

3. A.L. Bisno, Acute pharyngitis, N. Engl. J. Med., 344 (2001) 205-211.

4. M. Lindbæk, E.A. Høiby, G. Lermark, I.M. Steinsholt, P. Hjortdahl, Clinical symptoms and signs in sore throat patients with large colony variant $\beta$-haemolytic streptococci groups C or G versus group A, Br. J. Gen. Pract., 55 (2005) 615-619.

5. J.L.S. Sauver, A.L. Weaver, L.J. Orvidas, R.M. Jacobson, S.J. Jacobsen, Population-based prevalence of repeated group $A$ $\beta$-hemolytic streptococcal pharyngitis episodes, Mayo Clin. Proc., 81(2006) 1172-1176.

6. M.H. Danchin, S. Rogers, L. Kelpie, G. Selvaraj, N. Curtis, J.B. Carlin, T.M. Nolan, J.R. Carapetis, Burden of acute sore throat and group A streptococcal pharyngitis in schoolaged children and their families in Australia, Pediatrics, 120 (2007) 950-957.

7. S.J. Kim, Bacteriologic characteristics and serotypings of Streptococcus pyogenes isolated from throats of school children, Yonsei Med. J., 41 (2000) 56-60.

8. L. Shrestha, J.B.K. Khattri, K.N. Brahmadathan, J.S. Nagra, Prevalence of streptococcal pharyngitis among school children of pokhara valley, Nepal, J. Nepal Med. Assoc., 41 (2001) 253-257.

9. L. James, R.B. McFarland, An epidemic of pharyngitis due to a nonhemolytic group A streptococcus at Lowry Air Force Base, N. Engl. J. Med, 284 (1971) 750-752.

10. S. Malhotra-Kumar, S. Wang, C. Lammens, S. Chapelle, H. Goossens, Bacitracin-resistant clone of Streptococcus pyogenes isolated from pharyngitis patients in Belgium. J. Clin. Microbiol., 41 (2003) 5282-5284.
11. F.R. Cockerill, K.L. MacDonald, R.L. Thompson, F. Roberson, P.C. Kohner, J. Besser-Wiek, J.M. Manahan, J.M. Musser, P.M. Schlievert, J. Talbot, B. Frankfort, J.M. Steckelberg, W.R. Wilson, M.T. Osterholm, An outbreak of invasive group A streptococcal disease associated with high carriage rates of the invasive clone among school-aged children, JAMA, 277(1997) 38-43.

12. H.A. Haukness, R.R. Tanz, Jr.R.B. Thomson, D.K. Pierry, E.L. Kaplan, B. Beall, D. Jhonson, N.P. Hoe, J.M. Musser, S.T. Shulman, The heterogeneity of endemic community pediatric group a streptococcal pharyngeal isolates and their relationship to invasive isolates, J. Infect. Dis., 185 (2002) 915-920.

13. J.R. Carapetis, A.C. Steer, E.K. Mulholland, M. Weber, The global burden of group A streptococcal diseases, Lancet Infect. Dis, 5 (2005) 685-694.

14. K.R. Rijal, N. Dhakal, R.C. Shah, S. Timilsina, P. Mahato, S. Thapa, P. Ghimire, Antibiotic susceptibility of Group A Streptococcus isolated from throat swab culture of school children in Pokhara, Nepal, Nepal Med. Coll. J., 11 (2009) 238-40.

15. A.C. Seale, M.R. Davies, K. Anampiu, S.C. Morpeth, S. Nyongesa, S. Mwarumba, P.R. Smeesters, A. Efstratiou, R. Karugutu, N. Mturi, T.N. Williams, J.A.G. Scott, S. Kariuki, G. Dougan, J.A. Berkley, Invasive group A Streptococcus infection among children, rural Kenya, Emerg. Infect. Dis., 22 (2016) 224.

16. M. Enöz, İ. Sevinç, H.M. İnançı, Erzurum'da üst solunum yolu enfeksiyonlarında A grubu beta hemolitik streptokok insidansı, Kulak Burun Bogaz Ihtis. Derg., 19 (2009) 285-288.

17. A. Özkaya-Parlakay, M. Uysal, A. Kara, Group A Streptococcal tonsillopharyngitis burden in a tertiary Turkish hospital, Turk. J. Pediatr., 54 (2012) 474.

18. B. Christenson, S.P. Sylvan, B. Noreen, Carriage of multiresistant Streptococcus pneumoniae among children attending day-care centres in the Stockholm area, Scand. J. Infect. Dis., 29 (1997) 555-558.

19. I. Sevinc, M. Enoz, The prevalence of group A beta-hemolytic streptococcus in healthy Turkish children in day-care centers in Ankara, Chang Gung Med. J., 31 (2008) 554-558. 